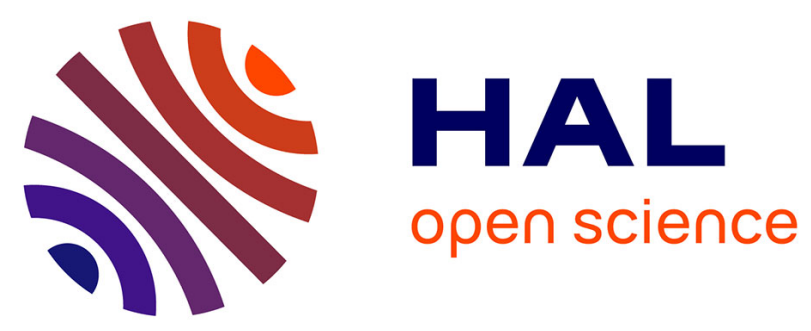

\title{
Infrared, Raman and NMR investigations of risedronate adsorption on nanocrystalline apatites
}

Farid Errassifi, Stéphanie Sarda, Allal Barroug, Ahmed Legrouri, Hocine Sfihi, Christian Rey

\section{- To cite this version:}

Farid Errassifi, Stéphanie Sarda, Allal Barroug, Ahmed Legrouri, Hocine Sfihi, et al.. Infrared, Raman and NMR investigations of risedronate adsorption on nanocrystalline apatites. Journal of Colloid and Interface Science, 2014, vol. 420, pp. 101-111. 10.1016/j.jcis.2014.01.017 . hal-01092765

\section{HAL Id: hal-01092765 https://hal.science/hal-01092765}

Submitted on 9 Dec 2014

HAL is a multi-disciplinary open access archive for the deposit and dissemination of scientific research documents, whether they are published or not. The documents may come from teaching and research institutions in France or abroad, or from public or private research centers.
L'archive ouverte pluridisciplinaire HAL, est destinée au dépôt et à la diffusion de documents scientifiques de niveau recherche, publiés ou non, émanant des établissements d'enseignement et de recherche français ou étrangers, des laboratoires publics ou privés. 


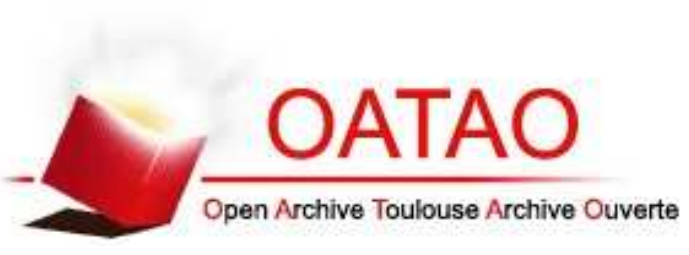

\title{
Open Archive TOULOUSE Archive Ouverte (OATAO)
}

OATAO is an open access repository that collects the work of Toulouse researchers and makes it freely available over the web where possible.

This is an author-deposited version published in : http://oatao.univ-toulouse.fr/ Eprints ID : 12073

To link to this article : DOI:10.1016/j.jcis.2014.01.017

URL : http://dx.doi.org/10.1016/j.jcis.2014.01.017

\begin{abstract}
To cite this version :
Errassifi, Farid and Sarda, Stéphanie and Barroug, Allal and Legrouri, Ahmed and Sfihi, Hocine and Rey, Christian Infrared, Raman and NMR investigations of risedronate adsorption on nanocrystalline apatites. (2014) Journal of Colloid and Interface Science, vol. 420 . pp. 101-111. ISSN 0021-9797
\end{abstract}

Any correspondance concerning this service should be sent to the repository administrator: staff-oatao@listes-diff.inp-toulouse.fr 


\title{
Infrared, Raman and NMR investigations of risedronate adsorption on nanocrystalline apatites
}

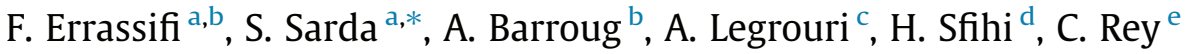 \\ a CIRIMAT, INPT-CNRS-UPS, Université de Toulouse, Université Paul Sabatier, Toulouse, France \\ ${ }^{\mathrm{b}}$ LPCME, CNRST-URAC 20, Faculté des Sciences Semlalia, University Cadi Ayyad, Marrakech, Morocco \\ 'School of Science \&' Engineering, Al Akhawayn University, Ifrane, Morocco \\ ${ }^{\mathrm{d}}$ Laboratoire de Physique et d'Etude des Matériaux, ESPCI, Paris, France \\ e CIRIMAT, INPT-CNRS-UPS, Université de Toulouse, ENSIACET, Toulouse, France
}

Keywords:

Adsorption

Bisphosphonate

Hydroxyapatite

Nanocrystalline apatite

Risedronate

Spectroscopy

\begin{abstract}
A B S T R A C T
The aim of the current work was to study the physico-chemical interactions of a bisphosphonate molecule, risedronate, with a well-characterised synthetic nanocrystalline apatite (NCA) as a model bone mineral. We adopted a global approach, using complementary physico-chemical techniques such as FTIR RAMAN and NMR spectroscopies in order to learn more about the interaction process of risedronate with the apatitic surface. The results obtained suggest that risedronate adsorption corresponds to an ion substitution reaction with phosphate ions occurring at the crystal surface. This mechanism explains the greater amount adsorbed $(\mathrm{N})$ for NCA, compared to well crystallised stoichiometric hydroxyapatite, attributable to the well-developed hydrated layer at the surface of the nanocrystals. However, most calcium ions remain attached to the solid phase and the formation of insoluble risedronate calcium salts must also be considered as a competitive reaction to the adsorption. Thus a calcium risedronate salt was synthesised and fully characterised for comparison to the solids after adsorption. Following spectroscopic results, it can be concluded that a strong interaction was established between risedronate ions and calcium ions at the apatitic surface. However, under these experimental conditions there is no nucleation of a distinct calcium risedronate salt and the apatite crystals retain their integrity.
\end{abstract}

\section{Introduction}

Bisphosphonates (BPs) are currently the most prescribed drugs for the treatment of diseases involving bone disorders such as osteoporosis or Paget's disease [1,2]. BPs are non-hydrolysable analogues of pyrophosphate characterised by a structure in which the oxygen bridge in pyrophosphate groups has been replaced by a carbon with various side chains (P-C-P). Their mechanisms of action are related to both their physicochemical and biological activities. Like pyrophosphate, BPs present a high affinity for adsorption onto apatite crystals due to the strong attraction of phosphonate groups for calcium, and thereby prevent mineral dissolution and bone resorption, inhibiting osteoclast activity [1,3]. Preclinical studies with different BPs showed that these antiresorptive agents

Abbreviations: BP, bisphosphonate; NCA, nanocrystalline apatite; HA, well crystallised stoichiometric hydroxyapatite.

* Corresponding author. Address: CIRIMAT, INPT-CNRS-UPS, Université de Toulouse, Université Paul Sabatier, 4 Allée Emile Monso, BP 44362, 31030 Toulouse Cedex 04, France. Fax: +33 (0)5 34323499.

E-mail address: stephanie.sarda@iut-tlse3.fr (S. Sarda). not only inhibit bone loss, but can also increase bone mass and resistance to fracture [2].

BPs are currently administered by a systemic route and, besides their low bioavailability, generate some undesirable side effects such as fever and gastrointestinal disturbances such as ulcers $[4,5]$. Moreover, osteonecrosis of the jaw has been observed, especially with intravenous preparations [6]. Thus, various investigations have been performed to elucidate the molecular interactions between BPs and bone or calcium phosphates compounds to better understand their retention phenomena. Although some studies have reported the release of phosphate ions during adsorption of several molecules, including BPs, suggesting an ion exchange reaction, this phenomenon has rarely been quantified and the adsorption process remains unclear. Mukherjee et al. [7] showed, for example, that the binding of pamidronate onto bone results in a strong chemisorption process, releasing one inorganic phosphate per bisphosphonate bound [7]. The interaction of calcium phosphate compounds with zoledronate appears to result in a surface adsorption of the drug, driven by an ion-exchange mechanism between phosphate and phosphonate groups on the solid surface $[8,9]$. Cukrowski et al. [10] reported that etidronate 
molecules are adsorbed through binding of their phosphonate groups to surface calcium sites of hydroxyapatite, as evidenced by Raman and solid state NMR spectroscopy measurements. Moreover several authors evidenced the great affinity of bisphosphonates for calcium ions to promote the precipitation of calcium-BP salts [10-12]. The formation of calcium-BP complexes or salts, resulting from the reaction of bone or calcium phosphates with BP, was postulated but very few studies have been carried out to prove it [10]. The formation of crystalline needles of calcium zoledronate was observed in the case of the interaction of $\beta$-tricalcium phosphate ( $\beta$-TCP) with zoledronate in an aqueous medium [13]. The formation of surface complexes was also reported for the interaction of phosphoserine with hydroxyapatite [14].

Furthermore, most of these studies have generally focused on well-crystallised calcium phosphates such hydroxyapatite (HA) [15-17]. Only a few studies have been devoted to the interaction of BPs with nanocrystalline apatites (NCA) analogous to bone mineral $[18,19]$. As for bone mineral, these supports have the particularity to present a structured hydrated surface layer, as evidenced by spectroscopic methods, that contains mineral ions in "nonapatitic" environments easily exchangeable $[20,21]$ and may affect its surface properties [22]. Consequently, the aim of this work was to study the physico-chemical interactions of a bisphosphonate molecule, risedronate (Fig. 1), on a well-characterised synthetic nanocrystalline apatite as a model bone mineral. The interaction phenomena between risedronate molecules and the nanocrystals were determined through adsorption reactions involving physicochemical characterisation of the solid and liquid, and were compared with a well-crystallised stoichiometric hydroxyapatite. To throw light on the possible formation of a separate phase in the reacted apatite, the calcium salt of risedronate was synthesised, fully characterised and compared with the sodium salt of risedronate. For this, we adopted a global approach using complementary physico-chemical techniques such as FTIR, RAMAN and NMR spectroscopies in order to learn more about the interaction process of risedronate with the apatitic surface.

\section{Materials and methods}

\subsection{Synthesis of apatite samples}

A nanocrystalline carbonated apatite (NCA), analogous to bone mineral, was prepared by a double decomposition reaction, at physiologic $\mathrm{pH}$, by mixing a cationic solution of $\mathrm{Ca}\left(\mathrm{NO}_{3}\right)_{2} \cdot 4 \mathrm{H}_{2} \mathrm{O}$ ( $0.29 \mathrm{M}$ in $750 \mathrm{~mL}$ deionised water) and an anionic one containing ammonium hydrogenophosphate and sodium bicarbonate $(0.45 \mathrm{M}$ $\left(\mathrm{NH}_{4}\right)_{2} \mathrm{HPO}_{4}$ and $0.71 \mathrm{M}$ of $\mathrm{NaHCO}_{3}$ in $1500 \mathrm{~mL}$ deionised water) [23]. The calcium solution was poured rapidly into the anionic solution at room temperature $\left(20^{\circ} \mathrm{C}\right)$. The large excess of phosphate and carbonate ions used had a buffering effect and allowed the $\mathrm{pH}$ to stabilise at around 7.4. The suspension was left to mature at room temperature for 6 days without stirring and was then filtered, washed with deionised water until free ammonium and nitrate counter ions were eliminated, and then lyophilised.

The well crystallised stoichiometric hydroxyapatite (HA) was synthesised by double decomposition between $\left(\mathrm{NH}_{4}\right)_{2} \mathrm{HPO}_{4}$ $\left(433.3 \mathrm{~mL}, \quad 1.54 \mathrm{M}\right.$ in deionised water) and $\mathrm{Ca}\left(\mathrm{NO}_{3}\right)_{2} \cdot 4 \mathrm{H}_{2} \mathrm{O}$

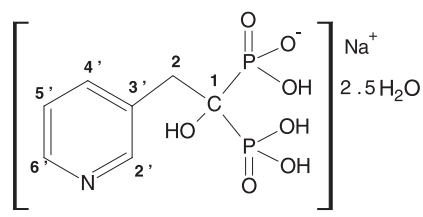

Fig. 1. Molecular structure of 1-hydroxy-2-(3-pyridinyl)ethylidene bisphosphonic acid monosodium hemipentahydrate salt.
(1100 mL, $1 \mathrm{M}$ in deionised water). The phosphate solution was added dropwise for about $3 \mathrm{~h}$ into the calcium solution maintained at $90^{\circ} \mathrm{C}$ under continuous stirring [24]; the $\mathrm{pH}$ of the suspension was around 10. After filtration, the precipitate was washed and lyophilised. Although stoichiometric hydroxyapatite has often been used to study the adsorption properties of bioactive molecules such as bisphosphonates, it appears rather different from bone mineral, described as a non-stoichiometric nanocrystalline apatite containing carbonate and/or hydrogen-phosphate ions. HA was used in this study as a reference for synthetic apatite.

\subsection{Preparation of the calcium salt of risedronate}

The risedronate (1-hydroxy-2-(3-pyridinyl)ethylidene bisphosphonic acid monosodium hemipentahydrate salt, named BP) used as adsorbate in this study was provided by Procter \& Gamble Pharmaceutical (Fig. 1). The calcium risedronate sample was prepared by dropwise addition of a solution of calcium nitrate $\mathrm{Ca}\left(\mathrm{NO}_{3}\right)_{2} \cdot 4 \mathrm{H}_{2} \mathrm{O}$ $(10 \mathrm{~mL}, 200 \mathrm{mM}, \mathrm{pH}=6)$ into a solution of risedronate $(25 \mathrm{~mL}$, $40 \mathrm{mM}, \mathrm{pH}=10$ ); these reactants were dissolved in deionised and decarbonated water with a calcium to risedronate molar ratio of $2: 1$. The mixture obtained (final $\mathrm{pH}=9.7$ ) was maintained under stirring for $1 \mathrm{~h}$ at $25^{\circ} \mathrm{C}$ and left to sit overnight in a closed vial. The resulting precipitate, denoted as $\mathrm{Ca}_{2} \mathrm{BP}$, was then filtered using $0.45 \mu \mathrm{m}$ cellulose filters, washed with deionised decarbonated water and dried at $37^{\circ} \mathrm{C}$ for $20 \mathrm{~h}$.

\subsection{Adsorption experiments}

Adsorption experiments were carried out at physiological temperature $\left(37 \pm 1{ }^{\circ} \mathrm{C}\right)$, by dispersing $50 \mathrm{mg}$ of apatite sample with $5 \mathrm{~mL}$ of risedronate solutions (concentration ranging from 0 to $12 \mathrm{mM}$ ) in a polyethylene tube. The latter were prepared by dissolving the appropriate amount of risedronate in an aqueous $1 \mathrm{mM} \mathrm{KCl}$ solution (standard solution); the $\mathrm{pH}$ of the obtained solutions was adjusted to 7.4 using hydrochloric acid and potassium hydroxide solutions. After sonication for 1-3 min, the suspensions were incubated for $1 \mathrm{~h}$ without stirring and centrifuged for $20 \mathrm{~min}$ at $5000 \mathrm{rpm}$. This equilibration time was previously determined from kinetic experiments using risedronate concentrations of 0.86 and $1.41 \mathrm{mM}$ for HA and NCA, respectively (data not shown). Blanks containing only the adsorbate, prepared and incubated in the solutions corresponding to the adsorption tests but without apatite solid, were used as controls.

After centrifugation, the solids obtained were washed with deionised water and lyophilised. The supernatants were filtrated on $0.2 \mu \mathrm{m}$ Millipore filters.

\subsection{Solution analysis}

The phosphate content of the solutions obtained after adsorption was determined by colorimetry of phospho-vanado-molybdic acid at $460 \mathrm{~nm}$ (Hewlett Packard 8452A Diode Array Spectrophotometer). The quantity of calcium ions was measured by inductively coupled plasma atomic emission spectroscopy (ICP-AES, Horiba, Jobin Yvon, 2004, Ultima 2).

The risedronate concentration in the filtrates was determined using UV spectrophotometric absorption at $262 \mathrm{~nm}$ (Hewlett Packard 8452A Diode Array Spectrophotometer). This wavelength corresponds to the maximum absorbance of the pyridine group. The calibration curve ranged from 0 to $0.43 \mathrm{mM}$. The molar absorption coefficient deduced from all calibration curves obtained was approximately $\quad 3.77 \times 10^{3} \mathrm{~L} \mathrm{~mol}^{-1} \mathrm{~cm}^{-1} \quad\left( \pm 0.13 \times 10^{3} \mathrm{~L} \mathrm{~mol}^{-1}\right.$ $\left.\mathrm{cm}^{-1}\right)$ at $\mathrm{pH}$ 7.4. This value is close to that reported $\left(3.90 \times 10^{3}\right.$ $\mathrm{L} \mathrm{mol}^{-1} \mathrm{~cm}^{-1}$ at $\mathrm{pH}$ 7) in the literature [25]. 
The quantity of risedronate adsorbed $Q\left(\mathrm{~mol} / \mathrm{m}^{2}\right)$ was then determined from the relation:

$Q=V(\Delta C) / W$

where $V(\mathrm{~L})$ is the volume of the solution in contact with $W(\mathrm{~g})$ of apatite, and $\Delta C(\mathrm{~mol} / \mathrm{L})$ is the difference between the initial and final equilibrium concentrations of risedronate. The values for the amounts of risedronate adsorbed by NCA and HA, performed in triplicate, were reproducible within a range of $5 \%$.

\subsection{Solid phases characterisation}

\subsubsection{X-ray diffraction}

The solid phases were characterised by X-ray diffraction (CPS 120 INEL) using the $\mathrm{K} \alpha_{1}$ radiation of a cobalt anticathode $(\lambda=1.78892 \AA)$. Apparent crystallite sizes were calculated from the (002) and (310) lines using the Scherrer's equation [26].

\subsubsection{FTIR spectroscopy}

The infrared spectrum of each powder was recorded over the $400-4000 \mathrm{~cm}^{-1}$ range with a Thermo Nicolet 5700 Fourier-transform infrared (FTIR) spectrometer (2 mg sample/300 mg $\mathrm{KBr}$ ). Curve fittings in the $v_{4} \mathrm{PO}_{4}$ domain were performed using GRAMS/386 software. The band shape was considered Lorentzian in all instances and the baseline was always linear, fixing or varying parameters (position and width) to provide the best curve fit. The relative band integrated intensities were defined as the ratio of the peak area to the total area of the phosphate bands.

\subsubsection{Raman spectroscopy}

Raman spectra of the samples were generated on a Horiba, Jobin-Yvon Labram HR800 confocal microspectrometer, equipped with a helium-neon LASER $(\lambda=632.82 \mathrm{~nm})$. The spectral resolution was $2 \mathrm{~cm}^{-1}$, the laser power was $2 \mathrm{~mW}$ and integration times varied from 30 to $120 \mathrm{~s}$. All spectra were recorded over a wavelength range of $200-1800 \mathrm{~cm}^{-1}$. Three spectral accumulations were averaged.

\subsection{4. ${ }^{31} \mathrm{P}$ solid state NMR}

${ }^{31} \mathrm{P}$ Single Pulse Excitation (SPE)-Magic Angle Spinning (MAS) measurements were done at $242.47 \mathrm{MHz}$ with a Bruker ASX 500 NMR spectrometer operating in a static field of $11.7 \mathrm{~T}$. A sample powder was filled into a $4 \mathrm{~mm}$ zirconia rotor and spun at $12 \mathrm{kHz}$. The recycle delay was $200 \mathrm{~s}$ for all the measurements, in accordance with the ${ }^{31} \mathrm{P}$ spin lattice relaxation times measured by saturation. The number accumulation was 32 . The ${ }^{31} \mathrm{P}$ chemical shifts were referenced to an external standard aqueous $85 \%$ $\mathrm{H}_{3} \mathrm{PO}_{4}$ solution.

\subsection{Chemical analysis of samples}

The composition of the solids was determined after dissolution in nitric acid. Calcium content was determined by complexometry with EDTA and phosphate content by UV spectrophotometry at $460 \mathrm{~nm}$ (Single beam UV/Vis Hitachi U-1100 spectrophotometer) using phospho-vanado-molybdic acid [27]. The relative error in the level of calcium and phosphate was $0.5 \%$ at. The determination of the atomic $\mathrm{Ca} / \mathrm{P}$ ratio of the precipitate had a relative error of $1 \%$ at. The quantity of carbonate ions in the NCA sample was measured by coulometry (UIC, Inc. CM 5014 coulometer with CM 5130 acidification unit).

\subsection{Specific surface area}

The specific surface area of the investigated samples was measured by nitrogen adsorption according to the BET method (Quantachrome NOVA-1000 Ver 3.70).

\subsection{Thermogravimetric analyses}

Thermogravimetric analyses (TGA-DTA) were performed using a Setaram Instrumentation SETSYS evolution system, with a heating rate of $3{ }^{\circ} \mathrm{C} / \mathrm{min}$, from $25^{\circ} \mathrm{C}$ to $500{ }^{\circ} \mathrm{C}(30.00 \pm 0.01 \mathrm{mg}$ of each sample).

\subsection{Transmission electron microscopy}

Transmission electron microscopy (TEM) micrographs were recorded in the secondary electron mode on a JEOL JEM $2100 \mathrm{~F}$ microscope set at an acceleration tension of $200 \mathrm{kV}$.

\section{Results and discussion}

\subsection{Characterisation of HA and NCA samples}

Chemical analyses for NCA and HA gave Ca/P ratios of 1.53 and $1.64( \pm 0.01)$, respectively, and determined the level of carbonate at $4.5 \%$ wt. $( \pm 0.5 \%)$ for NCA.

Fig. 2 shows X-ray diffraction (XRD) diagrams of the solids synthesised. The X-ray diffraction pattern of the HA sample corresponded to a well crystallised apatitic phase, while the NCA sample exhibited broad peaks illustrating the poorly crystalline feature of the apatitic phase prepared. The latter pattern appeared very analogous to those observed for bone samples [28]. No additional crystalline phase was detected. The mean crystallite dimensions derived from Scherrer's formula applied to apatitic diffraction lines (002) and (310) were evaluated for HA and NCA:L(002) was equal to 57.4 and $29.5 \mathrm{~nm}( \pm 0.5 \mathrm{~nm})$, and $\mathrm{L}(310)$ values were 27.5 and $9.0 \mathrm{~nm}( \pm 0.5 \mathrm{~nm})$, respectively. These values confirm that apatitic crystals were elongated along the $c$ axis of the hexagonal structure of the apatite $\left(\mathrm{L}_{(002)}>\mathrm{L}_{(310)}\right)$ [28]. The crystal dimension appeared smaller for the nanocrystalline apatite sample than for HA. These results were confirmed by TEM observation (Fig. 3 ).

The specific surface areas were evaluated at $59 \mathrm{~m}^{2} / \mathrm{g}( \pm 0.5 \%)$ for $\mathrm{HA}$ and $201 \mathrm{~m}^{2} / \mathrm{g}( \pm 0.5 \%)$ for NCA. The specific surface area of NCA appears about 3.4 times higher than that of HA sample in agreement with TEM and XRD results.

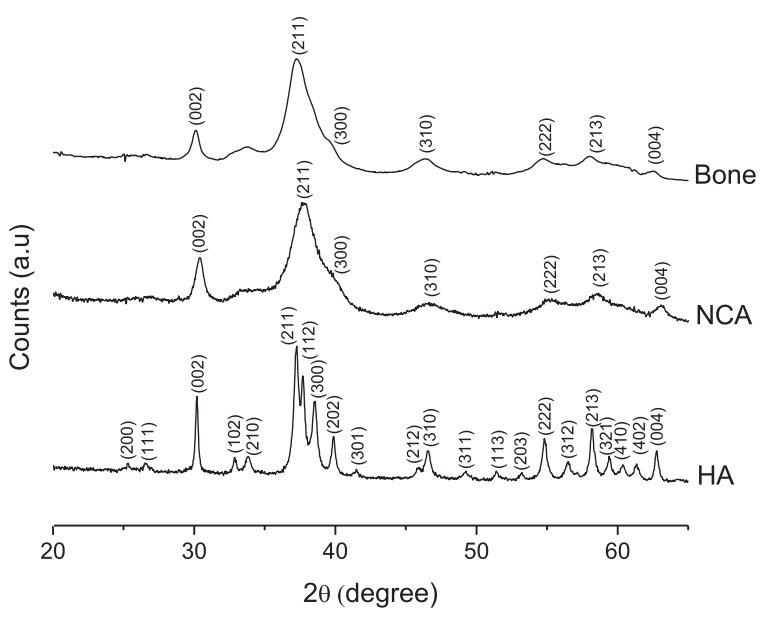

Fig. 2. XRD diagrams of the synthesised hydroxyapatite (HA) and nanocrystalline apatite (NCA) compared with bone mineral. 


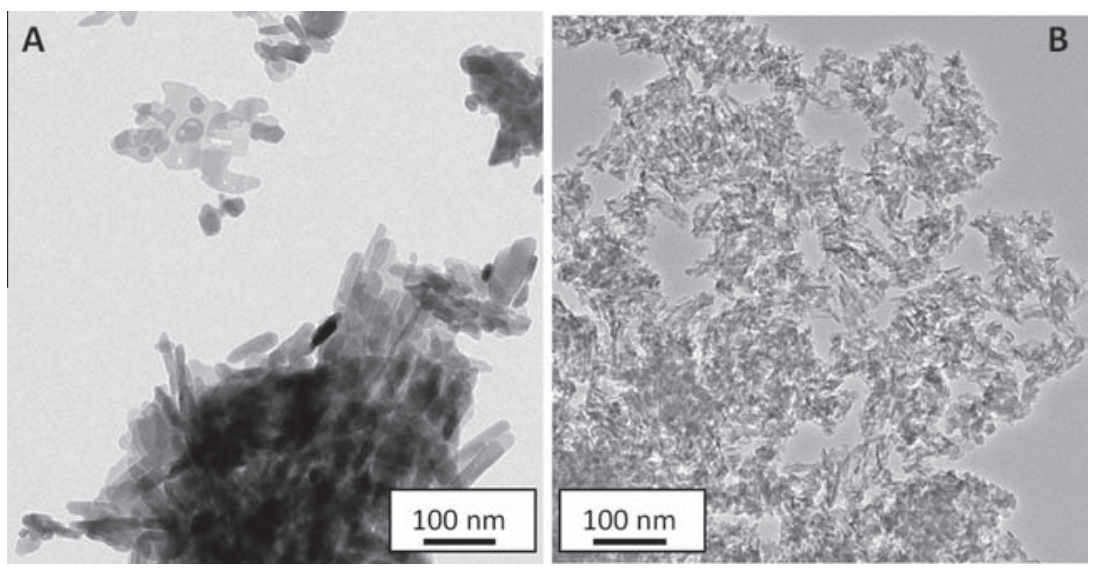

Fig. 3. TEM observation of (A) HA and (B) NCA.

The FTIR spectrum of HA showed bands corresponding to apatitic calcium phosphate compounds (Fig. 4A): $\mathrm{PO}_{4}^{3-}$ vibration bands at $550-600 \mathrm{~cm}^{-1}\left(v_{4}\right), 961 \mathrm{~cm}^{-1}\left(v_{1}\right)$ and $1000-1100 \mathrm{~cm}^{-1}\left(v_{3}\right)$, and $\mathrm{OH}$ bands at 630 and $3560 \mathrm{~cm}^{-1}$, characteristic of an apatitic environment [29]. The weak band at $875 \mathrm{~cm}^{-1}$ can be assigned to $\mathrm{HPO}_{4}^{2-}$ ions, confirming that the powder is a slightly calcium-deficient HA, in accordance with the chemical analyses. The infrared spectrum of NCA exhibited broader phosphate bands and no $\mathrm{OH}$ vibration was observed. Additional bands were evidenced in the $v_{4} \mathrm{PO}_{4}$ domain (Fig. 4B) by curve fitting analysis, corresponding to non-apatitic environments of $\mathrm{PO}_{4}^{3-}\left(620 \mathrm{~cm}^{-1}\right)$ and $\mathrm{HPO}_{4}^{2-}$ $\left(530 \mathrm{~cm}^{-1}\right)$ ions present in the hydrated surface layer [30]. Moreover, the presence of $\mathrm{CO}_{3}$ vibrations was observed at 871,1419 and $1476 \mathrm{~cm}^{-1}$ [20]. Type A and type B apatitic environments and labile species [31] could also be seen by curve fitting in the $v_{2} \mathrm{CO}_{3}$ domain (data not shown). These results confirm the presence of labile phosphate and carbonate ions in a hydrated surface layer of NCA that has been shown to be able to undergo exchange.

Raman spectra of the HA and NCA powders synthesised (Fig. 5) showed characteristic lines of apatite phosphate groups in accordance with the FTIR studies: the $v_{1}\left(960 \mathrm{~cm}^{-1}\right), v_{2}(430-$ $\left.450 \mathrm{~cm}^{-1}\right), v_{3}\left(1040-1074 \mathrm{~cm}^{-1}\right)$, and $v_{4}\left(590-608 \mathrm{~cm}^{-1}\right)$ modes of $\mathrm{PO}_{4}^{3-}$ [22]. For NCA, additional $\mathrm{CO}_{3}^{2-}$ vibration mode was detected at $1073 \mathrm{~cm}^{-1}\left(v_{1}\right)$ attributable to type $\mathrm{B}$ carbonate substitutions [32]. These lines overlapped the $v_{3}$ of $\mathrm{PO}_{4}^{3-}$.

The ${ }^{31} \mathrm{P}$ SPE-MAS solid NMR spectra of HA and NCA are shown in Fig. 6. The spectrum of HA shows a characteristic thin line at $2.6 \mathrm{ppm}$ corresponding to orthophosphate species [33], whereas the spectrum of NCA presents a single asymmetric broad line at $3.3 \mathrm{ppm}$ due to the presence of $\mathrm{HPO}_{4}^{2-}$ in the apatite lattice [22].

\subsection{Adsorption experiments}

A kinetic study performed under the same experimental conditions revealed that the equilibrium concentration of risedronate adsorbed by HA and NCA crystals was reached in less than 20 min (data not shown). Therefore an incubation period of $1 \mathrm{~h}$ was applied in the adsorption experiments. The evolution of the amount of risedronate adsorbed from the diluted solutions ( $0-12 \mathrm{mM})$ as function of the equilibrium concentration in the solution is plotted in Fig. 7. The isotherms obtained exhibited a typical Langmuirian shape. Similar observations have been noted for the interactions of various bisphosphonates [16,34,35] and other biological molecules with apatite crystals $[17,36,37]$. The adsorption plateaus were reached at relatively low risedronate concentrations (initial concentration less than $1.5 \mathrm{mM}$ ), indicating a high affinity between the risedronate molecules and the mineral surface. A slight increase in $\mathrm{pH}$ values (up to 0.3 unit) was noticed during risedronate adsorption. The parameters of adsorption can be deduced from the Langmuir equation:

$Q=\frac{K N C_{e}}{\left(1+K C_{e}\right)}$

The term $Q$ corresponds to the amount of risedronate adsorbed $\left(\mu \mathrm{mol} / \mathrm{m}^{2}\right), C_{e}$ is the equilibrium concentration in the solution ( $\mathrm{mmol} / \mathrm{l}), N$ is the maximum amount adsorbed at saturation ( $\mu \mathrm{mol} /$ $\mathrm{m}^{2}$ ), and $K$ is the affinity constant $(\mathrm{L} / \mathrm{mmol})$. The latter is only an

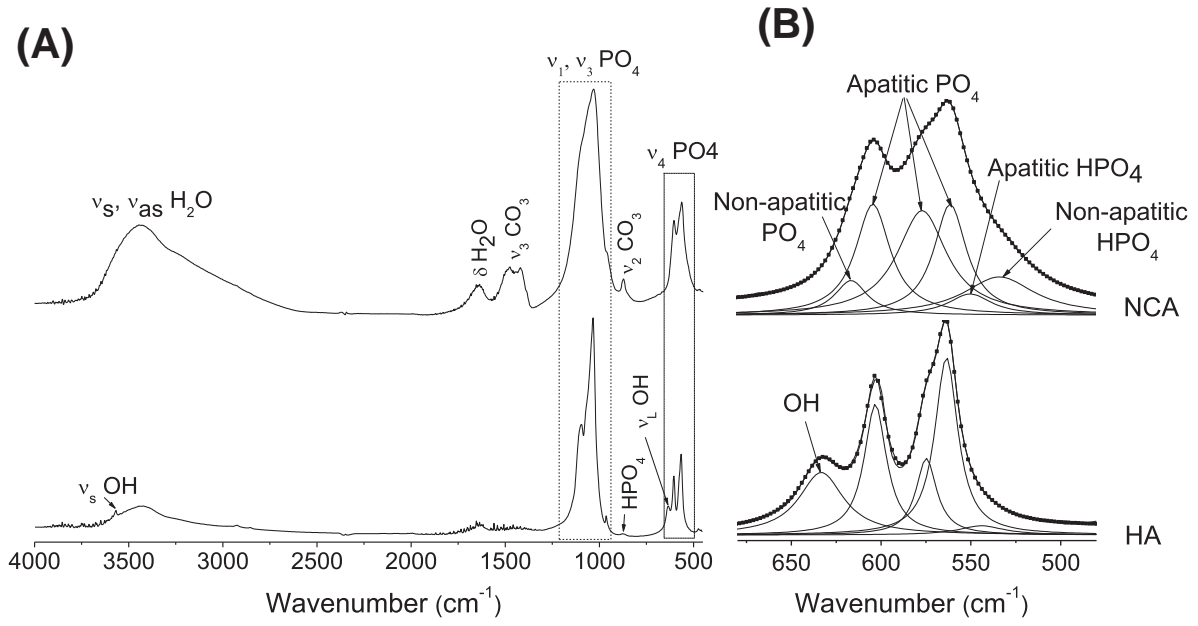

Fig. 4. (A) FTIR spectra of hydroxyapatite (HA) and nanocrystalline apatite (NCA) and (B) the corresponding decomposition in the $v_{4} \mathrm{PO}_{4}$ domain. 


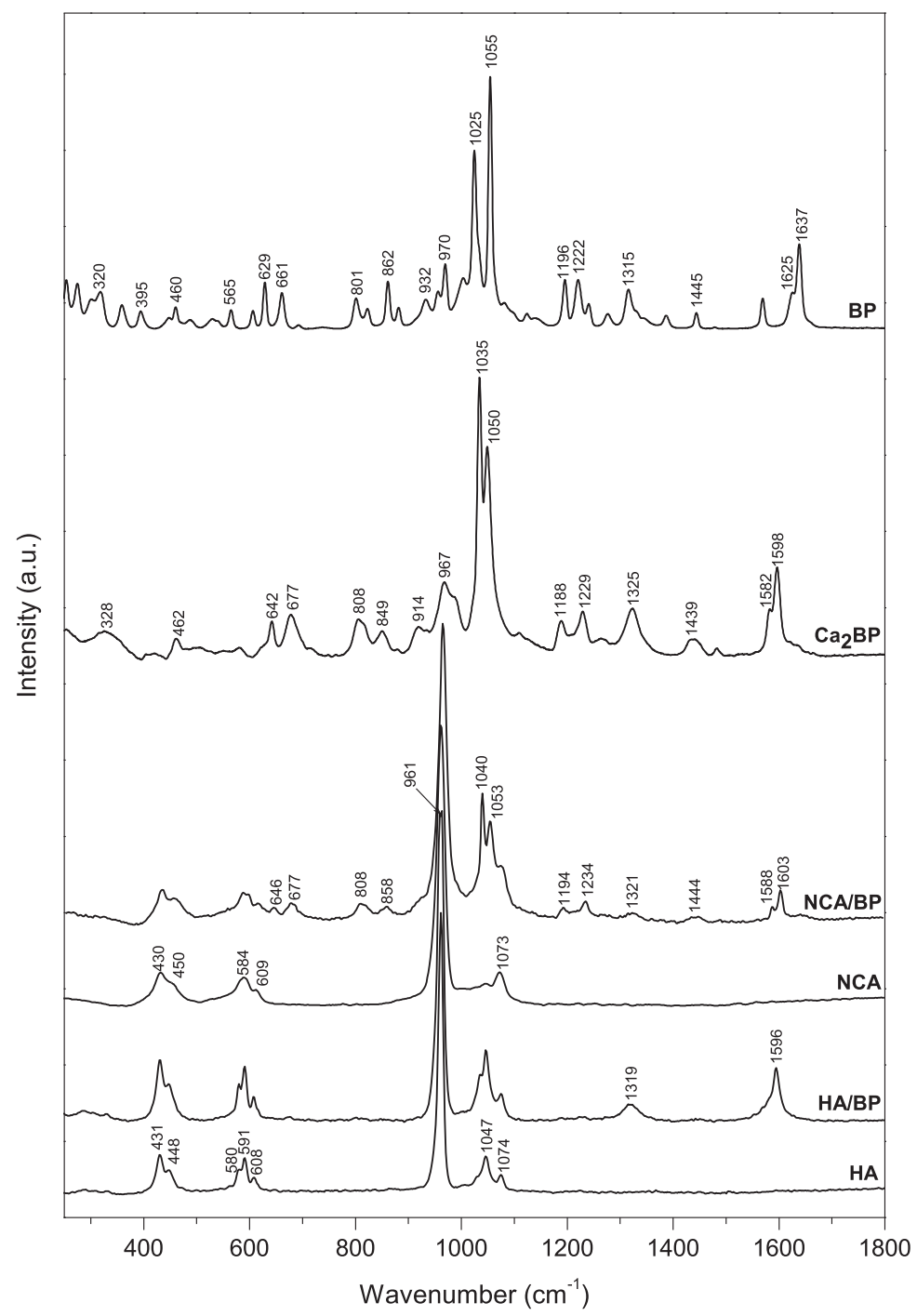

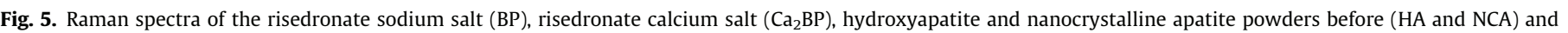
after uptake of risedronate (HA/BP and NCA/BP)

apparent parameter as the process is not completely reversible, as previously described [38]. The parameters of the isotherms ( $K$ and $N$ ) were determined by linear regression using the following linearised equation:

$$
C_{e} / Q=C_{e} / N+1 / K N
$$

The correlation coefficient obtained over the entire range of concentrations investigated was high $\left(r^{2}>0.99\right)$. The surface area occupied by one molecule of risedronate $(\sigma)$, calculated from the values of $N$ and the specific surface area of the solids, was on the order of $0.7 \mathrm{~nm}^{2} / \mathrm{mol}-$ ecule for HA and $0.5 \mathrm{~nm}^{2} /$ molecule for NCA. Table 1 gives the results of adsorption parameters obtained for risedronate and other bisphosphonates reported in the literature for comparative purposes [34,35], such as etidronate (1-hydroxyethylene-1,1-disphosphonate) and pamidronate (3-amino-1-hydroxy-1-phosphonopropanediphosphonate). The affinity constants $(K)$ were significantly higher with respect to our experimental data, probably due to difference in the properties of the HA powder used. As shown in our study, the HA surface cannot be fully covered by bisphosphonate molecules, and the authors supposed that the area occupied by one molecule is determined by the strong electrostatic interaction between the molecules of BP adsorbed. This interaction can be explained by the negative charge of the BP groups and is enhanced by the presence of the hydroxyl group attached to the central carbon and/or the positive charge of the pro- tonated amino group. Hence, the interaction depends on the nature of the bisphosphonate as shown by Mukherjee et al. [7]. Moreover, other authors assume that water molecules play an important role in the adsorption mechanism. Vitha et al. [34] consider that the apatitic support is solvated by a layer of water molecules and that the adsorption equilibrium can be described as a competition between adsorbed/free water and BP moieties on the surface of the crystals. Hence, a decrease in the local water concentration could favour affinity for the apatitic surface. This explanation, however, neglects the fact that the bonding of water molecules to BP is probably totally different, as shown by other studies.

Nevertheless, this hypothesis could explain the difference in adsorption parameters observed between HA and NCA supports. The lower affinity constant $(K)$ observed for NCA compared to HA could be attributed to the presence of a hydrated layer at the surface of the nanocrystals. Furthermore, the higher adsorption capability $(N)$ observed for the NCA sample with respect to HA can also be attributed to this well-developed hydrated layer containing relatively labile mineral ions [22]. Other factors such as the crystallinity index, chemical composition and crystal size may also influence the adsorption behaviour of such bioactive molecules on the apatitic support. Similar observations have been reported for the interaction of different bioactive species with calcium phosphates $[36,37,39]$. 


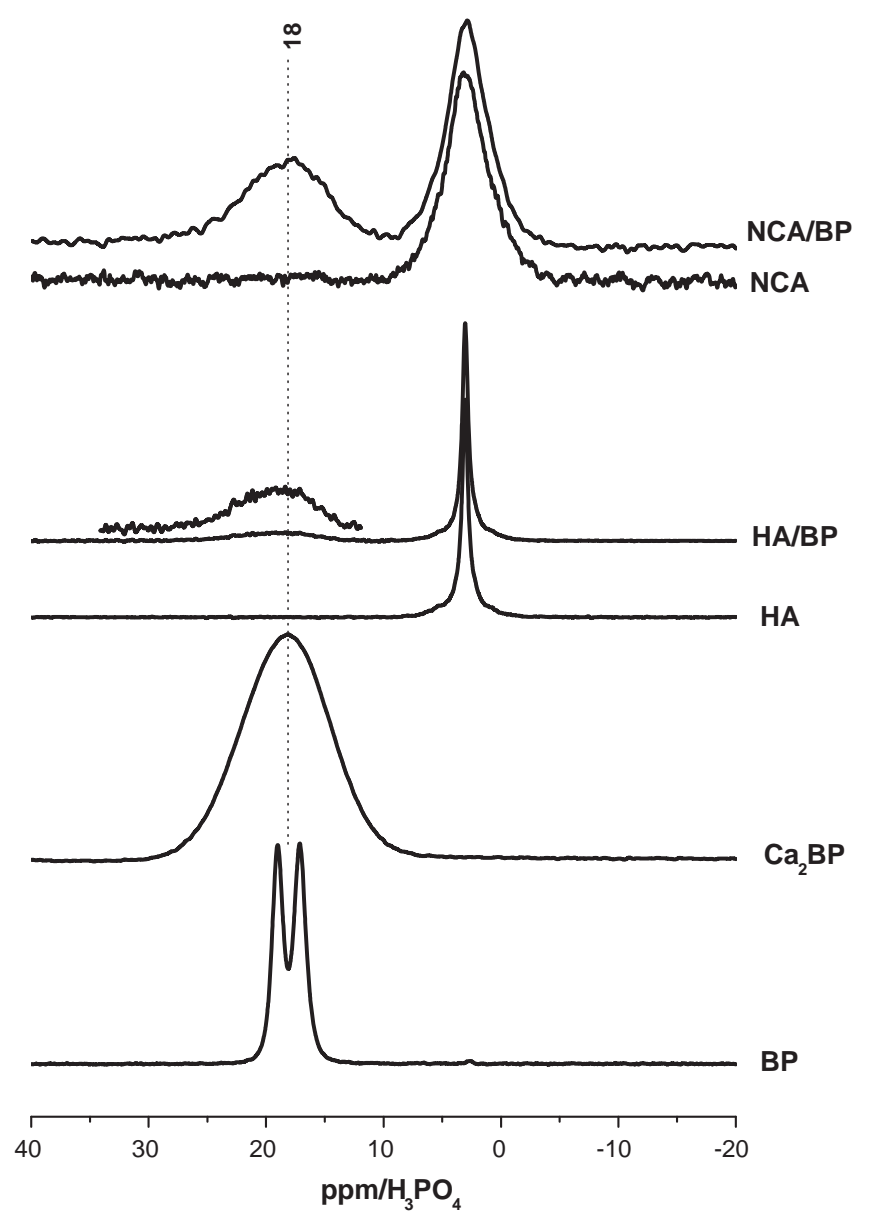

Fig. 6. ${ }^{31} \mathrm{P}$ SPE-MAS NMR spectra of the risedronate sodium salt (BP), risedronate calcium salt $\left(\mathrm{Ca}_{2} \mathrm{BP}\right)$, hydroxyapatite and nanocrystalline apatite powders before (HA and NCA) and after uptake of risedronate (HA/BP and NCA/BP).

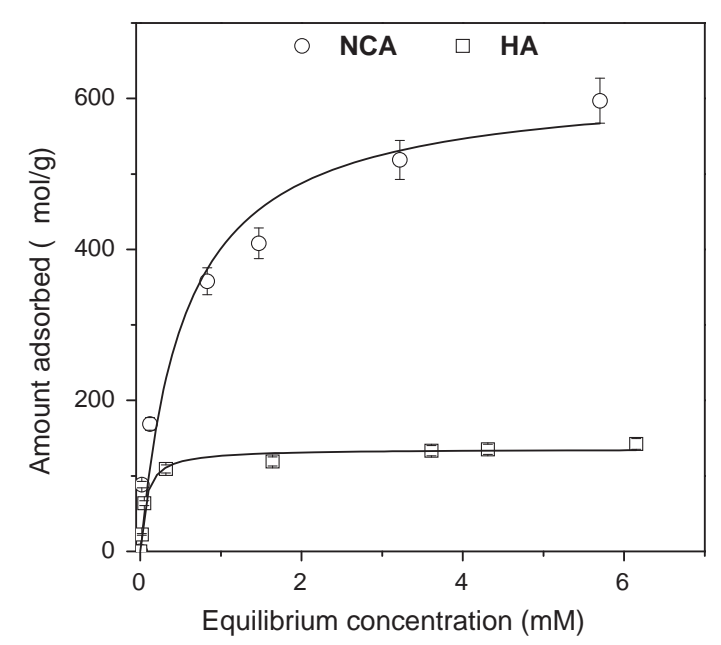

Fig. 7. Adsorption isotherms of risedronate onto hydroxyapatite (HA), ( $\square$ ) and nanocrystalline apatite (NCA), $(\bigcirc)$ at $\mathrm{pH} 7.4$ and $T 37^{\circ} \mathrm{C}$. The data fit the Langmuir isotherm.

\subsection{Analysis of the solutions after uptake of risedronate}

Analyses of the solutions obtained after uptake of bisphosphonate revealed that the binding of risedronate ions to the apatite surface affected the amount of calcium and phosphate ions in the solution. The evolution of these ions in solution as a function of risedronate adsorbed onto NCA is plotted in Fig. 8. The release of phosphate ions increased linearly (slope close to 1) upon uptake of risedronate. The content of phosphate ions in solution for the poorly crystalline sample (NCA) was significantly higher, due to the specific solubility behaviour of this type of apatite. Conversely, it was reported that the addition of phosphate ions to the medium inhibited the uptake of different anionic molecules [40,41] due to their competition for adsorbing sites on the apatite surface. These observations suggest that risedronate molecules substituted for phosphate ions on the mineral surface. As proposed by several authors $[8,9,18]$ for other BPs, it can be postulated that risedronate species participate in an ionic exchange process with active mineral ions on the surfaces of apatite crystals, particularly phosphates and/or carbonates, which share the same ionic sites at the crystal surface. This mechanism explains the higher uptake of NCA compared to HA (Table 1); this effect is attributed to the well-developed hydrated layer with relatively mobile mineral ions characteristic of non-apatitic environments on the surface of the nanocrystals [22]. The BP molecules adsorbed on bone minerals can only be detached from the mineral by the reverse action of phosphate ions and/or competitive adsorbing species.

Other phenomena determining the mineral ion concentrations in the solution, such as dissolution of the apatite and maturation and formation of ions pairs and/or soluble calcium complexes in the solution, or the formation of bisphosphonate calcium salts, must also be considered. In particular, it has been noted that adsorption of risedronate weakly influences the calcium content of the solution: the amount of calcium in the solution remained very low ( $<10 \mathrm{ppm}$ ) and increased only slightly at high risedronate concentrations (Fig. 8). Remembering that the content of free calcium ions in the solution is related to the phosphate level and is determined by the solubility equilibrium of the apatite, this weak increase in the level of calcium ions in the solution at elevated phosphate contents is difficult to explain because the solubility equilibrium of the apatite should then lead to a decrease in free calcium ions in solution. One possible explanation could be the formation of a soluble calcium complex or ion pairs involving risedronate molecules. Moreover, most calcium ions remain attached to the solid phase and the formation of insoluble risedronate calcium salts must also be considered a competing reaction to adsorption and compared to the solids after adsorption. To throw light on the possible formation of surface complexes in the reacted apatite, the prepared calcium salt of risedronate was characterised and compared with the risedronate sodium salt (BP) and the apatite samples obtained after uptake of risedronate (HA/BP and NCA/BP).

\subsection{Characterisation of the risedronate calcium salt}

XRD diagrams of the sodium risedronate salt used as adsorbate and the prepared calcium salt of risedronate are shown in Fig. 9. Sodium risedronate presents an XRD diagram similar to the data reported for the hemipentahydrate form of monosodium risedronate $[42,43]$. The crystal system determined in the literature is a monoclinic cell with unit cell dimensions of: $a=21.7463 \AA$, $b=8.9667 \AA ; c=15.1193 \AA, Z=8$, space group C2/c. The XRD data recorded for the $\mathrm{Ca}_{2} \mathrm{BP}$ precipitate clearly show an amorphous phase.

A thermogravimetric analysis was performed from $25^{\circ} \mathrm{C}$ to $300^{\circ} \mathrm{C}$ (data not shown) to provide information on the hydration level of the solids. Three weight losses were observed in the TG curve for the risedronate monosodium hemipentahydrate salt, at about 75,145 and $195{ }^{\circ} \mathrm{C}$, corresponding to a total weight loss of $12.8 \%$ and 2.5 water molecules of hydration. These results are in accordance with data reported in the literature: the first loss is 
Table 1

Adsorption parameters of bisphosphonates on NCA and HA at pH 7.4: maximum amount adsorbed at saturation ( $N)$ and apparent affinity constant $(K)$ derived from Langmuirtype equation plots.

\begin{tabular}{|c|c|c|c|c|c|}
\hline Adsorbent & Bisphosphonate & $N_{\text {mass }} \pm \Delta N(\mu \mathrm{mol} / \mathrm{g})$ & $N_{\text {surface }} \pm \Delta N\left(\mu \mathrm{mol} / \mathrm{m}^{2}\right)$ & $K \pm \Delta K(\mathrm{~L} / \mathrm{mmol})$ & Area $/$ molecule $(\sigma)\left(\mathrm{nm}^{2}\right)$ \\
\hline NCA & Risedronate & $643 \pm 60$ & $3.2 \pm 0.3$ & $2.1 \pm 1.0$ & 0.5 \\
\hline $\mathrm{HA}$ & Risedronate & $136 \pm 6$ & $2.3 \pm 0.1$ & $7.3 \pm 3.6$ & 0.7 \\
\hline $\mathrm{HA}$ & Etidronate & $189^{c}$ & $1.58 \pm 5.00^{\mathrm{b}}$ & $55.0 \pm 3.9^{b} 3.3^{c}$ & $\sim 0.8-1.0^{\mathrm{b}}$ \\
\hline HA & Pamidronate $^{\mathrm{b}}$ & & $1.82 \pm 7.00^{\mathrm{b}}$ & $44.0 \pm 10.0^{\mathrm{b}}$ & $\sim 0.8-1.0^{\mathrm{b}}$ \\
\hline
\end{tabular}

a $\sigma=S / N_{a}$, where $N_{a}$ is Avogadro's number and $S$ is the surface area of the adsorbent.

b From Ref. [34].

c From Refs. [1,35].

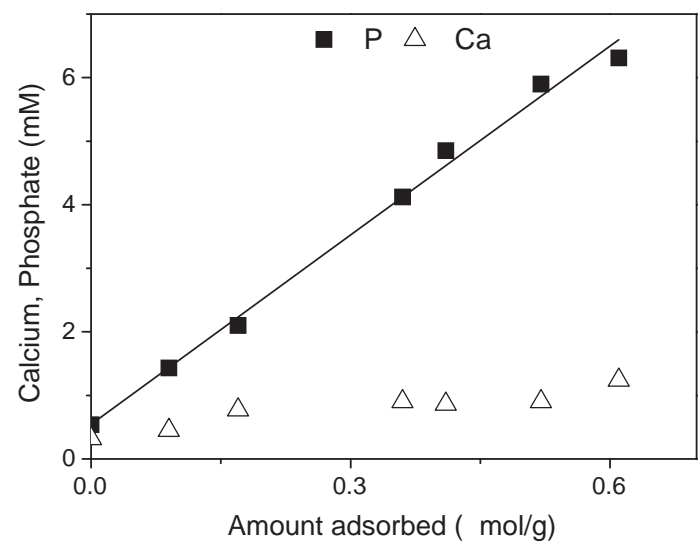

Fig. 8. Correlation between phosphate $(\boldsymbol{\square})$ and calcium $(\triangle)$ ions released in solution and risedronate adsorbed onto synthesised nanocrystalline apatite ( $1 \mathrm{mM}$ $\mathrm{KCl}$ solution at $\mathrm{pH} 7.4$ and $\mathrm{T} 37^{\circ} \mathrm{C}$ ). The phosphate content in solution appears linearly dependent on the amount of adsorbed risedronate, while the calcium content shows very faint variations. The results concerning HA were previously published $[17,38]$.

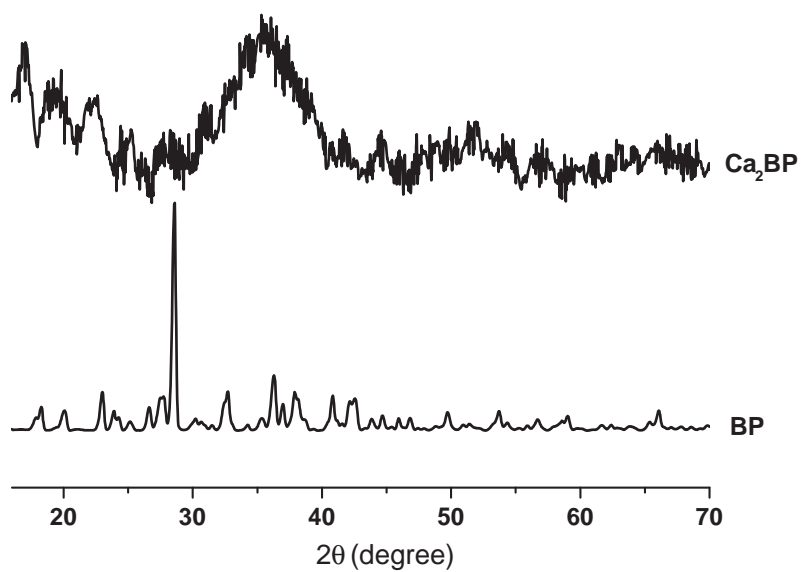

Fig. 9. XRD diagrams of the synthesised sodium (BP) and calcium salt $\left(\mathrm{Ca}_{2} \mathrm{BP}\right)$ of risedronate.

consistent with channel-type water of hydration, and the loss above $140^{\circ} \mathrm{C}$ corresponds to a lattice-type water of hydration $[42,43]$. The TG curve of the synthesised risedronate calcium salt showed a single weight loss at about $90{ }^{\circ} \mathrm{C}$, corresponding to a total weight loss of about $10 \%$ or about 2 water molecules of hydration per risedronate molecule.

The results of the chemical analyses of the risedronate calcium salt gave a Ca/BP ratio of 1.94 (close to 2) suggesting that two calcium ions reacted with one risedronate molecule. Such amorphous solids were also obtained in the case of a 2:1 calcium-HEDP (1-hydroxyethylidene-1,1-disphosphonic acid) precipitation [11].
The solubility constant of the calcium salt of risedronate was not found in the literature. However, regardless of the $\mathrm{Ca} / \mathrm{BP}$ ratio being close to 2 in the solid, the dissociation equilibrium of risedronate (Fig. 10), $[16,44,45]$ at the experimental $\mathrm{pH}$ used ( $\mathrm{pH}$ around 10 ), and taking into account the decrease in $\mathrm{pH}$ observed during the reaction process (final $\mathrm{pH}=9.7$ ), the main precipitation reaction can be described as follows:

$2 \mathrm{Ca}^{2+}+\mathrm{HBP}^{3-} \leftrightarrows \mathrm{Ca}_{2} \mathrm{BP}+\mathrm{H}^{+}$

Thus, the precipitation mechanism results in a stable neutral salt occurring when each calcium attacks two hydrogen atoms on each phosphonate group of BP and replaces the deprotonating species, such as proposed by Browning and Fogler for the interaction between calcium and HEPD (1-hydroxyethylidene-1,1-diphosphonic acid) [11] and applied in Fig. 11 for the synthesised risedronate calcium salt.

The infrared spectra of the monosodium risedronate compared to that of the calcium risedronate precipitate $\left(\mathrm{Ca}_{2} \mathrm{BP}\right)$ exhibited significant differences (Fig. 12). FTIR vibrations for a hemipentahydrated form of the monosodium risedronate salt were fully explained by Redman-Furey et al. [42]. The spectrum showed two distinct $\mathrm{OH}$ stretching bands at 3557 and $3614 \mathrm{~cm}^{-1}$ indicative of two different water populations within the crystal lattice. The shoulder observed at $3333 \mathrm{~cm}^{-1}$ is attributed to a $\mathrm{CO}-\mathrm{H}$ vibration corresponding to $\mathrm{OH}$ groups not associated with water but attached to the central carbon. Neither of these $\mathrm{OH}$ vibration bands were observed in the spectrum of the calcium risedronate salt. Only a broad band assigned to the $\mathrm{OH}$ bond of the $\mathrm{C}-\mathrm{OH}$ group was observed in the $3350 \mathrm{~cm}^{-1}$ region while the bands at about $3550-3600 \mathrm{~cm}^{-1}$ disappeared, indicating that water was removed from the crystal lattice as previously observed by thermal analysis. Similar observations have been done for other risedronate metal complexes [46].

Hydroxyl vibrations from $\mathrm{OH}$ groups associated with the $\mathrm{O}=\mathrm{P}-\mathrm{OH}$ of the phosphonate group produced broad bands in the spectral region between 1600 and $2725 \mathrm{~cm}^{-1}$ for the risedronate sodium salt, but not in the $\mathrm{Ca}_{2} \mathrm{BP}$ spectrum because of the deprotonation of these $\mathrm{OH}$ groups and the binding with calcium ions.

The characteristic infrared bands of the phosphonate group $\left(\mathrm{PO}_{3}\right)$ were observed between 1000 and $1150 \mathrm{~cm}^{-1}$ for the risedronate sodium salt, overlapping with pyridine ring vibrations. They were shifted to a higher frequency $\left(\Delta v \sim 50 \mathrm{~cm}^{-1}\right)$ for the calcium salt, evidencing the strong interaction of phosphonate groups with calcium in the synthesised $\mathrm{Ca}_{2} \mathrm{BP}$. This band is relatively broad in accordance with the low crystallinity observed by XRD.

Fig. 5 presents Raman spectra in the region between 200 and $1800 \mathrm{~cm}^{-1}$ of the monosodium risedronate salt and the synthesised calcium salt. The broader bands that are observed in the $\mathrm{Ca}_{2} \mathrm{BP}$ spectrum, compared to those of the sodium salt, are related to the amorphous state revealed by XRD. The Raman spectra of both the sodium and calcium salts are dominated by vibration bands associated with the substituted pyridine ring in the chemical structure between 1000 and $1650 \mathrm{~cm}^{-1}$ [42]. 


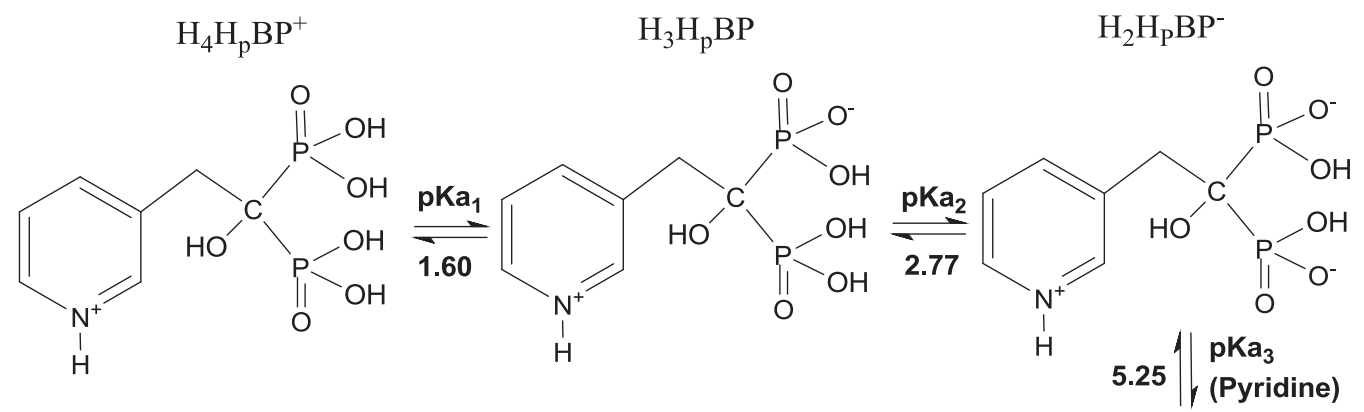<smiles>O=P([O-])([O-])C(O)(Cc1cccnc1)P(=O)([O-])[O-]</smiles>

$\mathrm{BP}^{4-}$<smiles>O=P([O-])([O-])C(O)(Cc1ccncc1)P(=O)([O-])O</smiles>

$\mathrm{HBP}^{3-}$<smiles>O=P([O-])(O)C(O)(Cc1cccnc1)P(=O)([O-])O</smiles>

$\mathrm{H}_{2} \mathrm{BP}^{2-}$

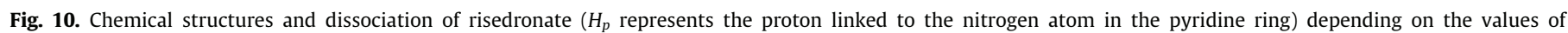
equilibrium dissociation constants $\mathrm{p} K_{\mathrm{as}}$ from the literature $[16,44,45]$.<smiles>O=P12O[Ge]O[Te](=O)(O[C@]1(O)Cc1cccnc1)O2</smiles>

Fig. 11. Chemical structure proposed for the synthesised calcium risedronate salt $\left(\mathrm{Ca}_{2} \mathrm{BP}\right)$.

The risedronate sodium salt showed two intense bands in the $1025-1055 \mathrm{~cm}^{-1}$ region assigned to $\mathrm{C}-\mathrm{H}$ pyridine ring deformation, strongly impacted by hydrogen bonding between the pyridine ring and an adjacent phosphate group [42]. These bands were shifted to 1035 and $1050 \mathrm{~cm}^{-1}$, respectively, in the $\mathrm{Ca}_{2} \mathrm{BP}$ form, possibly due to modifications in the hydrogen bonding involving the pyridine group and the adjacent phosphonate group in the calcium salt.
In the $1450-1700 \mathrm{~cm}^{-1}$ spectral region, the Raman spectrum of BP showed a medium band at $1637 \mathrm{~cm}^{-1}$ with a shoulder at $1625 \mathrm{~cm}^{-1}$ and a weaker one at $1445 \mathrm{~cm}^{-1}$ associated with the substituted pyridine ring, while two bands were observed for $\mathrm{Ca}_{2} \mathrm{BP}$ at higher frequencies, 1596 and $1582 \mathrm{~cm}^{-1}$, showing a change in the environment of the substituted pyridine ring induced by calcium binding. Pyridine rings do not participate in the coordination to calcium ions. However, the pyridine nitrogen participates in hydrogen bonding, as previously reported for different hydrates of risedronate $[43,46]$.

The characteristic Raman bands of the phosphonate groups $\left(\mathrm{PO}_{3}\right)$ in the risedronate sodium salt were observed at 862, 932, 970,1196 and $1222 \mathrm{~cm}^{-1}$ [10]. These vibration bands were also shifted after the interaction with calcium, towards lower wavenumbers at $849,914,967,1188$ and 1229 , respectively; this may be explained by changes in the $\mathrm{P}-\mathrm{O}$ environments due to probable coordination with $\mathrm{Ca}^{2+}$, slightly larger than the sodium ion, induc-

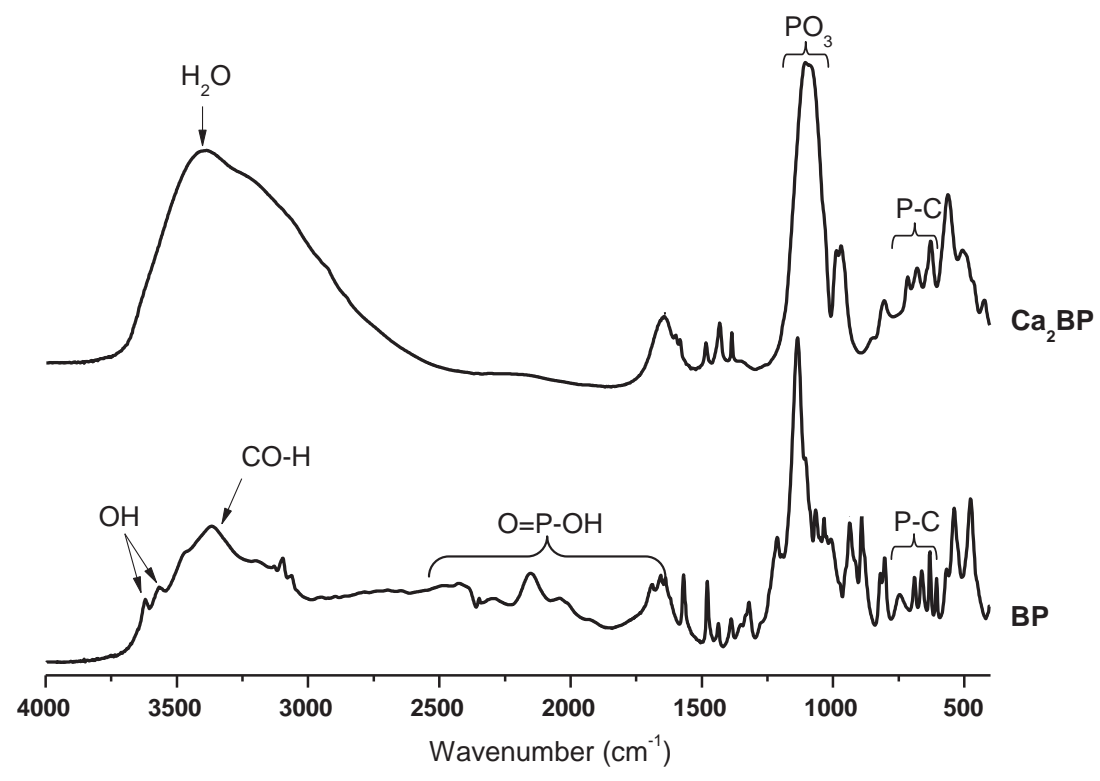

Fig. 12. FTIR spectra of the monosodium risedronate salt (BP) and the calcium salt $\left(\mathrm{Ca}_{2} \mathrm{BP}\right)$. 
ing a shift to higher frequencies, as observed by other authors for risedronate metal complexes [46].

The spectrum of the sodium salt showed two bands at 629 and $661 \mathrm{~cm}^{-1}$, related to the $v(\mathrm{C}-\mathrm{P})$ bond stretching vibration [10]. These bands were shifted to 642 and $677 \mathrm{~cm}^{-1}$ in the $\mathrm{Ca}_{2} \mathrm{BP}$ spectrum, due to the strong interaction between phosphate and calcium.

The ${ }^{31}$ P SPE-MAS NMR spectrum of the risedronate sodium salt exhibited two distinct and slightly resolved lines at 19.01 and $17.12 \mathrm{ppm}$ (Fig. 6) characteristic of the hemipentahydrated form of risedronate $[42,43]$. These lines are attributable to the two phosphonate groups resulting from the non-centrosymmetric crystal structures $[47,48]$. For the synthesised risedronate calcium salt, only a broad line appears at c.a. $18 \mathrm{ppm}$. Similar results have been reported by Grossmann et al. [15] and Mukherjee et al. [7] for adsorption of various bisphosphonates on synthetic hydroxyapatite and bone. The line broadening reflects a change in the electronic environment of the ${ }^{31} \mathrm{P}$ of the two phosphonate groups resulting from their interaction with calcium ions. This interaction could explain the amorphous structure of the sample as evidenced by XRD.

\subsection{Characterisation of the solids after uptake of risedronate}

FTIR spectra recorded for the solids after uptake of bisphosphonate and for the synthesised risedronate calcium salt are shown in Fig. 13. It can be seen that FTIR spectra of samples treated with risedronate solutions generated additional vibration bands before $900 \mathrm{~cm}^{-1}$ attributable to $\mathrm{P}-\mathrm{C}$ vibration [49]. The three bands centred at about 679,714 and $801 \mathrm{~cm}^{-1}$ are stronger in the NCA spectrum compared with HA, probably due to the greater amount of risedronate adsorbed compared with HA. These bands are present in the spectrum of the synthesised $\mathrm{Ca}_{2} \mathrm{BP}$; however, the positions of the two first bands for the risedronate sodium salt are shifted, respectively, to $690 \mathrm{~cm}^{-1}$ and $747 \mathrm{~cm}^{-1}$, while the latter band at $801 \mathrm{~cm}^{-1}$ was split. The perceptible change in the infrared spectra of the solids incubated with BP solutions is evidence that the bisphosphonate molecules interact with the calcium ions on the apatitic surface.

The Raman spectra of apatite samples before and after uptake of risedronate and for the risedronate calcium salt are illustrated in

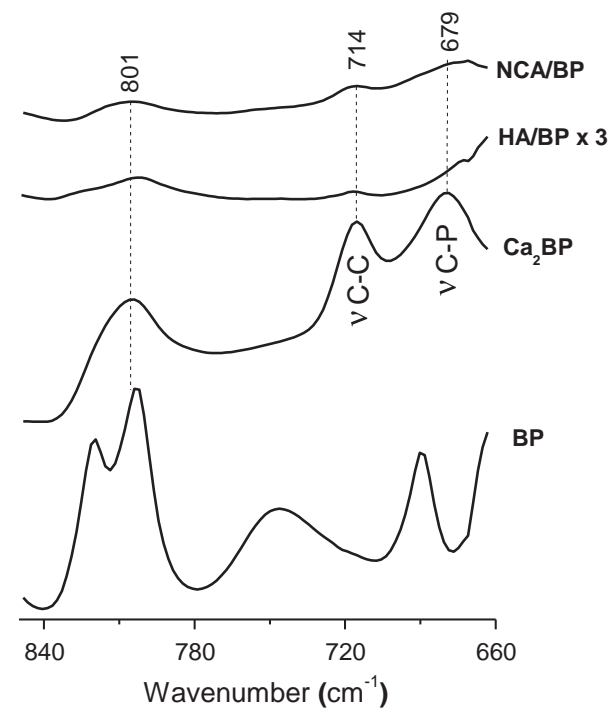

Fig. 13. FTIR spectra in the $660-850 \mathrm{~cm}^{-1}$ domain of the risedronate sodium salt $(\mathrm{BP})$, the synthesised calcium salt $\left(\mathrm{Ca}_{2} \mathrm{BP}\right)$, hydroxyapatite $(\mathrm{HA})$ and nanocrystalline apatite (NCA) after uptake of risedronate (NCA/BP and HA/BP) at pH 7.4 and $37^{\circ} \mathrm{C}$.
Fig. 5. Additional bands were observed for both apatitic minerals upon interaction with risedronate molecules. Like in the FTIR spectra, these bands are stronger in the NCA spectrum compared with $\mathrm{HA}$, due to the greater adsorption capability of risedronate for the nanocrystals as evidenced by the adsorption isotherms. The characteristic Raman bands of the phosphonate group $\left(\mathrm{PO}_{3}\right)$ of risedronate between 850 and $1250 \mathrm{~cm}^{-1}$ were covered by the vibration bands of the orthophosphate group $\left(\mathrm{PO}_{4}\right)$ in the apatitic structure; only the band at about $1040 \mathrm{~cm}^{-1}$ and two weaker ones at 808 and $858 \mathrm{~cm}^{-1}$ were observed. In addition, additional bands in the vibrational domain of the pyridine ring were detected: a broad band at $1596 \mathrm{~cm}^{-1}$ in the HA spectrum, and a split one at 1588 and $1603 \mathrm{~cm}^{-1}$ in the NCA spectrum, associated with the substituted pyridine ring, visible in the $\mathrm{Ca}_{2} \mathrm{BP}$ spectrum and shifted towards lower frequencies in the spectrum of the risedronate sodium salt. Two weaker bands were observed at 646 and $677 \mathrm{~cm}^{-1}$, attributable to $\mathrm{C}-\mathrm{P}$ vibrations, and others between 1150 and $1500 \mathrm{~cm}^{-1}$ due to pyridine ring quadrant stretches; these bands are also similar to those noticed in the $\mathrm{Ca}_{2} \mathrm{BP}$ spectrum and shifted with respect to the risedronate sodium salt. In accordance with the FTIR results, the characterisation of the supports after uptake with risedronate by Raman spectroscopy evidences a strong interaction of the risedronate molecules with calcium ions on the surface of the solids, regardless of the amounts adsorbed and the nature of the apatitic support.

The ${ }^{31} \mathrm{P}$ SPE-MAS spectra of the sample powders after uptake of risedronate, compared to those before contact and to that of the synthesised risedronate calcium salt (Fig. 6), reveal a weak broad line centred at $18 \mathrm{ppm}$ attributable to ${ }^{31} \mathrm{P}$ nuclei present in the two phosphonate groups. This observation is evidence for the presence of risedronate species on the apatite surface. The broadness of this line, which is very different from that in the risedronate sodium salt, suggests a lack of crystallinity as proposed by Grossmann et al. for the interaction of some bisphosphonates with hydroxyapatite [15]. Such a broad line is also present in the ${ }^{31} \mathrm{P}$ NMR spectrum of the synthesised risedronate calcium salt, whereas two thinner separated lines were observed for the sodium salt.

Regardless of the results of the characterisation of the apatitic solids uptake of risedronate compared with the calcium-risedronate salt, a strong interaction exists between risedronate and calcium at the surface of the apatite samples. The analysis of the solutions after interaction with risedronate shows that most calcium ions remain attached to the solid phase and the formation of insoluble risedronate calcium salts must also be considered as a competitive reaction to the adsorption, even if the solubility of this compound is unknown. Indeed, spectroscopic characterisation of the apatite supports the existence of vibrational bands present in the synthesised $\mathrm{Ca}_{2} \mathrm{BP}$ spectrum. The reaction on the apatitic surface could then be described as a dissolution-reprecipitation phenomenon. Such reactions have been previously proposed, for example in the adsorption of zoledronate [9], and were represented by Pascaud et al. [18] by the following equation:

$\mathrm{Ca}_{X}\left(\mathrm{PO}_{4}\right)_{\text {solid }}+(X / 2) \mathrm{BP}_{\text {solution }}^{4-} \rightarrow X / 2 \mathrm{Ca}_{2} \mathrm{BP}_{\text {solid }}+\left(\mathrm{PO}_{4}\right)_{\text {solution }}^{2 \mathrm{X}-}$

where $X$ is the $\mathrm{Ca} / \mathrm{P}$ ratio of the apatite and $\left(\mathrm{PO}_{4}\right)$ phosphate species (undetermined protonation states). In the case of a dissolutionreprecipitation phenomenon and the formation of a $\mathrm{Ca}_{2} \mathrm{BP}$ salt, the amount of phosphate released versus risedronate remaining in solution would be equal to $2 / X$, i.e. 1.31 for NCA. However the $\mathrm{P}_{\text {released }} / \mathrm{BP}$ ratio obtained in this study for NCA appears close to 1 , which would exclude the formation of a calcium salt of $\mathrm{Ca}_{2} \mathrm{BP}$. Furthermore, other arguments can exclude the dissolution-reprecipitation phenomenon. No other phase was detected by XRD although the calcium risedronate salt is amorphous and difficult to detect 
by this technique. Similarly, we could not observe foreign phases by SEM (data not shown). Furthermore, it should be noted that a dissolution-reprecipitation reaction would not lead to a Langmuir adsorption equilibrium in the range of concentrations explored. If risedronate calcium salts were formed as a separate phase, the phosphate released would continue to increase with the increase in risedronate in the solution and no plateau would be reached. Under these experimental conditions there is no nucleation of a distinct calcium risedronate salt and the apatite crystals retain their integrity. On the basis of these experimental observations the main driving force still seems to be an ion-exchange process involving risedronate species and active mineral ions of the apatite crystals, particularly phosphate.

Besides, previous studies concerning the reversibility of the adsorption process [38] have shown a strong interaction between risedronate and apatitic surface as the adsorption of bisphosphonate molecules is irreversible with respect to dilution and the amount adsorbed is not altered by dilution of the adsorption solution or even on washing of the samples.

However, based on the spectroscopic results, a strong interaction between risedronate and calcium at the surface of the apatite samples seems to exist. The shifts of vibration bands observed can be attributed to $\mathrm{BP} /$ apatitic mineral interactions. These interactions modify the molecular environment and can be explained by the creation of bonds between different moieties of BP and the apatitic surface, in particular the pyridine nitrogen from risedronate and phosphate groups from the apatite. Such results are in agreement with recent studies suggesting that the 3-D configuration of amino-bisphosphonates (N-BPs), such as zoledronate and risedronate, and the orientation of their nitrogen play an important role in apatitic mineral binding affinity [2]. 3-D computational modelling was tested to examine the potential for additional interactions of the nitrogen moiety in the N-BPs and suggested that some $\mathrm{N}-\mathrm{BPs}$ can form $\mathrm{N}-\mathrm{H}-\mathrm{O}$ hydrogen bonds on the HA surface [50]. Such bonds could involve changes in the pyridine ring environments of risedronate and modify its vibrational modes, which explain shifts observed in the Raman spectra.

Moreover in a previous study concerning tiludronate adsorption on an apatitic surface [18] a binding mechanism was proposed involving both phosphate substitution and interaction with calcium groups of the HA surface, in two steps: (1) an interaction of a BP molecule with $\mathrm{Ca}^{2+}$ ions on the apatitic surface involving partial or total deprotonation of phosphonate groups; (2) the released protons interact with surface hydrogen phosphate groups, yielding $\mathrm{H}_{2} \mathrm{PO}_{4}^{-}$ions, which are then released. Supported by the results obtained in this study, a third step could be added in the case of risedronate: (3) nitrogen bonding of a $\mathrm{BP}$ molecule with an $\mathrm{OH}$ group on the apatite surface and the formation of an $\mathrm{N}-\mathrm{H}-\mathrm{O}$ bond.

\section{Conclusion}

This study suggests that risedronate adsorption on apatitic supports corresponds to an ion substitution reaction with phosphate ions at the crystal surface. This mechanism explains the greater amount adsorbed $(\mathrm{N})$ for NCA, compared to the HA specimen, attributed to the well-developed hydrated layer with relatively mobile mineral ions at the surface of the nanocrystals corresponding to nonapatitic environments. However, most calcium ions remain thus attached to the solid phase, and the formation of insoluble risedronate calcium salts must also be considered as a competitive reaction to the adsorption. Thus, a calcium risedronate salt was synthesised and fully characterised for comparison with the solids after adsorption. Following the spectroscopic results, it can be concluded that a strong interaction is established between risedronate ions and calcium ions at the surface of the apatite samples. However under these experimental conditions there is no nucleation of a distinct calcium risedronate salt and the apatite crystals maintain their integrity.

The combination of FTIR, Raman and solid NMR spectroscopies proved to be a powerful multidisciplinary approach for understanding the interaction of nanocrystalline apatites as a model of bone mineral and bisphosphonate molecules.

\section{Acknowledgments}

This research was supported by the French Moroccan Volubilis integrated action \#MA/05/122. The authors thank Procter \& Gamble for the generous gift of the risedronate samples.

\section{References}

[1] G.A. Rodan, H.A. Fleisch, J. Clin. Investigation 97 (1996) 2692.

[2] R.G.G. Russell, N.B. Watts, F.H. Ebetino, M.J. Rogers, Osteoporosis Int. 19 (2008) 733.

[3] R.G. Russell, R.C. Muhlbauer, S. Bisaz, D.A. Williams, H. Fleisch, Calcif. Tissue Res. 6 (1970) 183.

[4] J. Mönkkönen, J. Similä, M.J. Rogers, Life Sci. 62 (1998) PL95.

[5] R. Coleman, R. Burkinshaw, M. Winter, H. Neville-Webbe, J. Lester, E. Woodward, J. Brown, Expert Opin. Drug Safety 10 (2011) 133.

[6] M. Kos, K. Luczak, Biosci. Hypotheses 2 (2009) 34.

[7] S. Mukherjee, Y. Song, E. Oldfield, J. Am. Chem. Soc. 130 (2008) 1264.

[8] A. Juillard, G. Falgayrac, B. Cortet, M.-H. Vieillard, N. Azaroual, J.-C. Hornez, G. Penel, Bone 47 (2010) 895.

[9] S. Josse, C. Faucheux, A. Soueidan, G. Grimandi, D. Massiot, B. Alonso, P. Janvier, S. Laib, P. Pilet, O. Gauthier, G. Daculsi, J. Guicheux, B. Bujoli, J.-M. Bouler, Biomaterials 26 (2005) 2073.

[10] I. Cukrowski, L. Popovic, W. Barnard, S.O. Paul, P.H. van Rooyen, D.C. Liles, Bone 41 (2007) 668

[11] F.H. Browning, H.S. Fogler, Langmuir 12 (1996) 5231.

[12] A.T. Kan, J.E. Oddo, M.B. Tomson, Langmuir 10 (1994) 1450

[13] H. Roussiere, F. Fayon, B. Alonso, T. Rouillon, V. Schnitzler, E. Verron, J. Guicheux, M. Petit, D. Massiot, P. Janvier, J.M. Bouler, B. Bujoli, Chem. Mater. 20 (2008) 182.

[14] D.N. Misra, J. Colloid Interface Sci. 194 (1997) 249.

[15] G. Grossmann, A. Grossmann, G. Ohms, E. Breuer, R. Chen, G. Golomb, H. Cohen, G. Hägele, R. Classen, Mag. Reson. Chem. 38 (2000) 11.

[16] G.H. Nancollas, R. Tang, R.J. Phipps, Z. Henneman, S. Gulde, W. Wu, A. Mangood, R.G.G. Russell, F.H. Ebetino, Bone 38 (2006) 617.

[17] F. Errassifi, A. Menbaoui, H. Autefage, L. Benaziz, S. Ouizat, V. Santran, S. Sarda, A. Lebugle, C. Combes, A. Barroug, H. Sfihi, C. Rey, in: A.C. Soc (Ed.), Pacific Rim Conference on Ceramic and Glass Technology, Vancouver, Canada, 2010, p. 159.

[18] P. Pascaud, P. Gras, Y. Coppel, C. Rey, S. Sarda, Langmuir (2013).

[19] B. Palazzo, M. Iafisco, M. Laforgia, N. Margiotta, G. Natile, C.L. Bianchi, D. Walsh, S. Mann, N. Roveri, Adv. Funct. Mater. 17 (2007) 2180.

[20] C. Rey, C. Combes, C. Drouet, H. Sfihi, A. Barroug, Mater. Sci. Eng. C 27 (2007) 198.

[21] Y. Wu, J.L. Ackerman, E.S. Strawich, C. Rey, H.M. Kim, M.J. Glimcher, Calcif. Tissue Int. 72 (2003) 610.

[22] D. Eichert, C. Drouet, H. Sfihi, C. Rey, C. Combes, Biomater. Res. Adv. 93 (2008).

[23] C. Rey, A. Hina, A. Tofighi, M.J. Glimcher, Cells Mater. 5 (1995) 345.

[24] J.C. Trombe. Contribution à l'étude de la décomposition et la réactivité de certaines apatites hydroxylées carbonatées ou fluorées alcalino-terreuses. Thesis, UPS, Toulouse, France, 1972.

[25] P.T. Vallano, S.B. Shugarts, W.F. Kline, E.J. Woolf, B.K. Matuszewski, J. Chromatogr. B 794 (2003) 23.

[26] A. Guinier, Théorie et technique de la radiocristallographie, Dunod, Paris, 1960.

[27] G. Charlot, Chim. Anal. Quant. (1974).

[28] H.M. Kim, C. Rey, M.J. Glimcher, Calcif. Tissue Int. 59 (1996) 58.

[29] J.C. Elliott, Structure and chemistry of the apatites and other calcium orthophosphates. Amsterdam ed., 1994.

[30] C. Rey, C. Combes, C. Drouet, A. Lebugle, H. Sfihi, A. Barroug, Mater. Werkstofftechnik 38 (2007) 996.

[31] S. Bohic, C. Rey, A. Legrand, H. Sfihi, R. Rohanizadeh, C. Martel, A. Barbier, G. Daculsi, Bone 26 (2000) 341.

[32] G. Penel, G. Leroy, C. Rey, E. Bres, Calcif. Tissue Int. 63 (1998) 475.

[33] J.P. Yesinowski, H. Eckert, J. Am. Chem. Soc. 109 (1987) 6274

[34] T. Vitha, V. Kubicek, P. Hermann, Z.I. Koar, H.T. Wolterbeek, J.A. Peters, I. Lukes, Langmuir 24 (2008) 1952.

[35] R. Claessens, Z.I. Kolar, Langmuir 16 (2000) 1360.

[36] S. Ouizat, A. Barroug, A. Legrouri, C. Rey, Mater. Res. Bull. 34 (1999) 2279.

[37] L. Benaziz, A. Barroug, A. Legrouri, C. Rey, A. Lebugle, J. Colloid Interface Sci. 238 (2001) 48

[38] A. Al-Kattan, F. Errassifi, A.M. Sautereau, S. Sarda, P. Dufour, A. Barroug, I. Dos Santos, C. Combes, D. Grossin, C. Rey, C. Drouet, Adv. Eng. Mater. 12 (2010) B224. 
[39] A. Barroug, L.T. Kuhn, L.C. Gerstenfeld, M.J. Glimcher, J. Orthop. Res. 22 (2004) 703.

[40] A. Barroug, A. Legrouri, C. Rey, Key Eng. Mater. 361-363 (2008) 79.

[41] S. Shimabayashi, Y. Tanizawa, K. Ishida, Chem. Pharm. Bull. 39 (1991) 2183.

[42] N. Redman-Furey, M. Dicks, A. Bigalow-Kern, R.T. Cambron, G. Lubey, C. Lester D. Vaughn, J. Pharm. Sci. 94 (2005) 893.

[43] C. Lester, G. Lubey, M. Dicks, G. Andol, D. Vaughn, R.T. Cambron, K. Poiesz, N. Redman-Furey, J. Pharm. Sci. 95 (2006) 2631.

[44] M. Takami, K. Suda, T. Sahara, K. Itoh, K. Nagai, T. Sasaki, N. Udagawa, N. Takahashi, Bone 32 (2003) 341.

[45] A.M. Hounslow, J. Carran, R.J. Brown, D. Rejman, G.M. Blackburn, D.J. Watts, J. Med. Chem. 51 (2008) 4170.
[46] B. Demoro, F. Caruso, M. Rossi, D. Benítez, M. Gonzalez, H. Cerecetto, B Parajón-Costa, J. Castiglioni, M. Galizzi, R. Docampo, L. Otero, D. Gambino, J. Inorganic Biochem. 104 (2010) 1252.

[47] V.A. Uchtmann, R.A. Gloss, J. Phys. Chem. 76 (1972) 9.

[48] L.M. Shkol'nikova, S.S. Sotman, E.G. Afonin, Sov. Phys. Crystallogr. 35 (1990) 850.

[49] G. Socrates, Infrared \& Raman Characteristic Group Frequencies: Tables \& Charts, third ed., John Wiley \& Sons, 2004.

[50] F.H. Ebetino, B.L. Barnett, R.G.G. Russell, Z. Henneman, G.H. Nancollas, Bone 38 (2006) S48. 